\title{
HUBUNGAN SUMBER AIR MINUM DENGAN KEJADIAN DIARE DI PROVINSI SUMATERA SELATAN
}

\author{
Marini $^{1 *}$, Dheli Ofarimawan ${ }^{1}$, Lasbudi P. Ambarita ${ }^{1}$ \\ ${ }^{1}$ Balai Penelitian dan Pengembangan Kesehatan Baturaja \\ JI. A.Yani KM.7 Kemelak Baturaja, 32111, Kabupaten Ogan Komering Ulu, Sumatera Selatan, Indonesia
}

\begin{abstract}
Diarrheal disease is the second leading cause of death in children under five years of age in the world with a mortality rate of around 525,000 children in 2017. According to basic health research (Riskesdas) in 2018, it is known that the prevalence of diarrhea based on the diagnosis of health workers was 6.8\%. This result show a $2.3 \%$ increase when compared to the previous Riskesdas in 2013, which was only 4.5\%. The prevalence of diarrhea in South Sumatera Province in 2018 was 5.5\%. This analysis aims to examine the relationship between drinking water sources used by the community on a daily basis and the incidence of diarrhea in South Sumatera Province using data from the National Socio-Economic Survey (Susenas) in 2018. The analysis used was bivariate with pearson correlation. The result show a very close relationship between drinking water sources and the incidence of diarrhea with and $R$ square value of 0,712 and show a positive relationship direction. This analysis conclude that the prevalence of diarrhea have a correlation with the use of tap water as drinking sources in South Sumatera Province. Health promotion in the form of information, education and communication (EIC) about the management of water sources for consumption needs to be continuosly pursued in an effort to improve public health.
\end{abstract}

Keywords: South Sumatera, diarrhea, tap water, rainwater.

\section{THE RELATIONSHIP OF DRINKING WATER SOURCES WITH THE INCIDENCE DIARRHEA IN SOUTH SUMATERA PROVINCE}

\begin{abstract}
Abstrak
Penyakit diare merupakan penyebab utama kedua kematian pada anak di bawah usia lima tahun di dunia dengan angka kematian sekitar 525.000 anak setiap tahunnya. Menurut data Riskesdas 2018 diketahui bahwa prevalensi diare berdasarkan diagnosis tenaga kesehatan adalah sebesar 6,8\%. Hal ini menunjukkan kenaikan 2,3\% jika dibandingkan dengan hasil Riskesdas 2013 yaitu hanya 4,5\%. Prevalensi diare untuk Provinsi Sumatera Selatan pada tahun 2018 sebesar 5,5\%. Analisis ini bertujuan untuk melihat hubungan sumber air minum yang digunakan sehari-hari oleh masyarakat dengan angka kejadian diare di Provinsi Sumatera Selatan menggunakan hasil olah data dari Survei Sosial Ekonomi Nasional (Susenas) tahun 2018. Analisis yang digunakan adalah bivariat dengan korelasi pearson. Hasil analisis data menunjukkan adanya hubungan yang sangat erat antara sumber air minum air ledeng dengan kejadian diare dengan nilai $R$ square sebesar 0,712 dan menunjukkan arah hubungan yang positif. Kesimpulan analisis ini menunjukkan bahwa angka kejadian diare berhubungan dengan penggunaan air ledeng sebagai sumber air minum. Promosi kesehatan berupa komunikasi, informasi dan edukasi (KIE) tentang pengelolaan sumber air untuk di konsumsi perlu terus digalangkan dalam upaya meningkatkan derajat kesehatan masyarakat.
\end{abstract}

Kata Kunci: Sumatera Selatan, diare, air ledeng, air hujan.

Naskah masuk: 24 April 2020; Review: 13 Mei 2020; Layak Terbit: 18 September 2020

*Alamat korespondensi penulis pertama: e-mail: riniebta@gmail.com; Telp: (0735) 325303 


\section{PENDAHULUAN}

Diare merupakan penyakit saluran pencernaan. Penderitanya mengalami kondisi buang air besar secara terus menerus dan feses yang dikeluarkan mengandung cairan yang berlebihan. Pada kondisi diare, buang air besar dapat terjadi tiga kali atau lebih dalam satu hari. Pasien diare akan mengalami kehilangan cairan tubuh sehingga dapat menyebabkan dehidrasi yang dapat menyebabkan kematian. . $^{1,2,3,4,5}$ Penyakit diare merupakan salah satu penyakit yang paling sering menyerang anak-anak di seluruh negara, hal ini dikarenakan angka morbiditas dan mortalitasnya yang masih tinggi. ${ }^{6}$

Berdasarkan data WHO, penyakit diare merupakan penyebab utama kedua kematian pada anak di bawah usia lima tahun di dunia dengan angka kematian sekitar 525.000 anak pada tahun 2017. ${ }^{7}$ Berdasarkan hasil Riskesdas Tahun 2018 diketahui bahwa prevalensi diare berdasarkan diagnosis tenaga kesehatan di Indonesia adalah sebesar 6,8\%. Hal ini meningkat jika dibandingkan dengan hasil Riskesdas 2013 yaitu hanya $4,5 \%$. Sedangkan prevalensi diare berdasarkan diagnosis tenaga kesehatan untuk Provinsi Sumatera Selatan sebesar $5,5 \%$ dengan prevalensi kejadian diare pada balita sebesar $10,7 \% .^{8}$

Secara klinis, diare dapat disebabkan oleh infeksi (infeksi bakteri, virus, parasit), malabsorbsi, alergi, keracunan (bahan kimia, racun yang terkandung atau diproduksi oleh jasad renik, ikan, buah-buahan, sayursayuran, algae, imunisasi, difisiensi dan lain sebagainya. ${ }^{9} \quad$ Beberapa penelitian menyebutkan bahwa faktor utama yang mempengaruhi terjadinya kejadian diare, khususnya pada balita adalah kesehatan lingkungan, diantaranya adalah penggunaan sarana air bersih, pengelolaan sampah dan limbah, perilaku hidup bersih, dan lainlain. ${ }^{10,11,12,13}$

Air menjadi sumber penyakit dikarenakan, vektor penyakit khususnya penyakit diare berkembang biak dan menular melalui air yang memiliki kualitas yang tidak baik. ${ }^{14}$ Penelitian yang dilakukan oleh Wandansari (2013) menyebutkan bahwa ada hubungan antara kualitas sumber air minum dengan kejadian diare. ${ }^{15}$ Pada Tahun 2015, Ayuningrum dan Salamah mengatakan bahwa sanitasi yang baik dan sumber air minum mempengaruhi insiden diare pada balita. ${ }^{16}$ Penelitian yang dilakukan Sari (2016), dengan menggunakan uji ChiSquare Test diperoleh hasil dengan nilai $p$ $=0,011$ yang artinya terdapat hubungan antara kejadian diare dengan sumber air yang dikonsumsi. Menurut Nurpauji dkk (2016) menyatakan bahwa sumber air minum merupakan faktor penting yang berkaitan dengan kejadian diare. Hal ini disebabkan karena sebagian besar kuman infeksius penyebab diare berasal dari air. ${ }^{17}$

Air merupakan sumber daya alam yang dibutuhkan oleh seluruh makhluk hidup, ketersediaan air dapat mengimbangi perkembangan di segala sektor kehidupan. ${ }^{18}$ Provinsi Sumatera Selatan memiliki sumber daya air tawar yang melimpah, tetapi hal ini tidak menjamin kualitas air yang digunakan oleh masyarakat. Hal ini dikarenakan melimpahnya sumber daya air ini tidak disinergikan dengan percepatan pembangunan infrastruktur air bersih. Menurut catatan Wahana Lingkungan Hidup (Walhi) bahwa ketersediaan air minum masih menjadi permasalahan di hampir seluruh kabupaten/kota Provinsi Sumatera Selatan. ${ }^{19}$ Menurut data BPS, Tahun 2018 proporsi rumah tangga yang memiliki akses air layak di Provinsi Sumatera Selatan adalah sebesar $65 \% .^{20}$ Masyarakat di Provinsi Sumatera Selatan memanfaatkan air minum untuk memenuhi kebutuhan air sehari-harinya dari berbagai sumber diantaranya adalah air ledeng, pompa, air dalam kemasan, sumur terlindung, sumur tak terlindung, mata air terlindung, air permukaan dan air hujan.

Berdasarkan hal tersebut, maka peneliti ingin mengkaji lebih lanjut hubungan sumber air minum yang digunakan sehari-hari oleh masyarakat di Provinsi Sumatera Selatan terhadap angka kejadian diare.

\section{METODE}

Analisis ini menggunakan hasil olah data Survei Sosial Ekonomi Nasional (Susenas) oleh BPS tahun 2018. Informasi yang diambil khusus Provinsi Sumatera Selatan berupa data persentase sumber air minum per jenis yang digunakan oleh masyarakat dan jumlah angka kejadian 
diare menurut Kabupaten/Kota. Desain penelitian yang digunakan pada survei Susenas adalah cross sectional study. Pengumpulan data Susenas dilakukan dari rumah tangga terpilih melalui wawancara tatap muka antara pencacah dengan responden. Analisis untuk mengetahui hubungan sumber air minum dengan kejadian diare yang digunakan adalah analisis bivariate dengan korelasi pearson. Variabel dependen pada analisis ini adalah kejadian diare di Provinsi Sumatera Selatan dan variabel independennya adalah sumber air minum ledeng, pompa, air dalam kemasan, sumur terlindung, sumur tak terlindung, mata air terlindung, air permukaan dan air hujan.
HASIL

Berdasarkan data hasil olah data Susenas BPS diketahui bahwa angka kejadian diare di Provinsi Sumatera Selatan mengalami penurunan yaitu tahun 2017 mencapai 176.295 dan tahun 2018 menjadi 166.002 kasus. Berikut ditampilkan grafik hasil analisis bivariabel antara kejadian diare dengan masingmasing sumber air minum yang digunakan oeh masyarakat di Provinsi Sumatera Selatan.

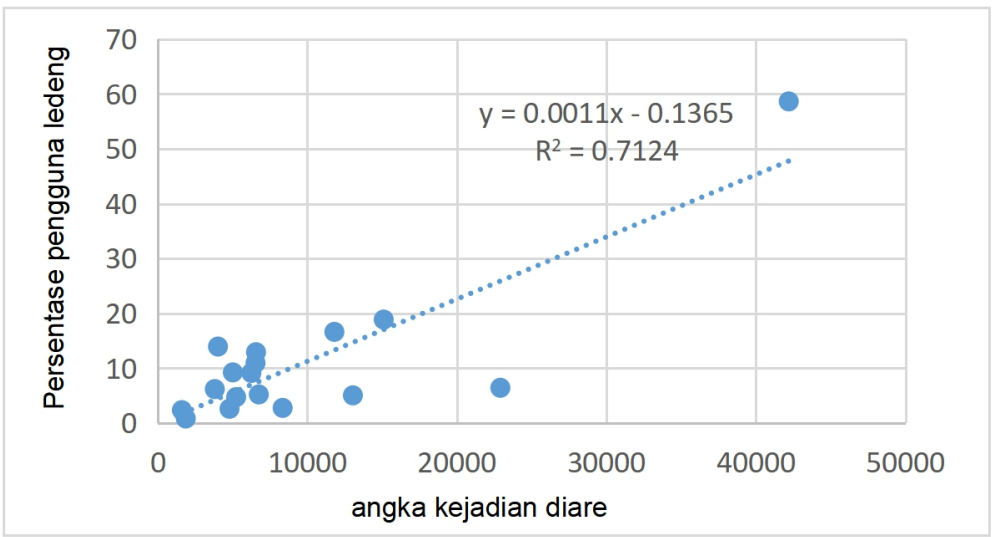

Gambar 1. Scatterplot kejadian diare dan air ledeng

Berdasarkan diagram pencar/scatterplot angka kejadian diare dan persentase pengguna sumber air minum air ledeng di Provinsi Sumatera Selatan (Gambar 1), diperoleh angka $R$ square $\left(R^{2}\right)$ sebesar 0,712 atau $71,2 \%$. Hal ini menunjukkan bahwa terdapat hubungan yang kuat antara variabel dependen (kejadian diare) dan variabel independen (pengguna air ledeng). Hubungan ini bersifat positif secara statistik yaitu makin tinggi persentase pengguna air ledeng maka makin banyak kemungkinan kejadian diare.

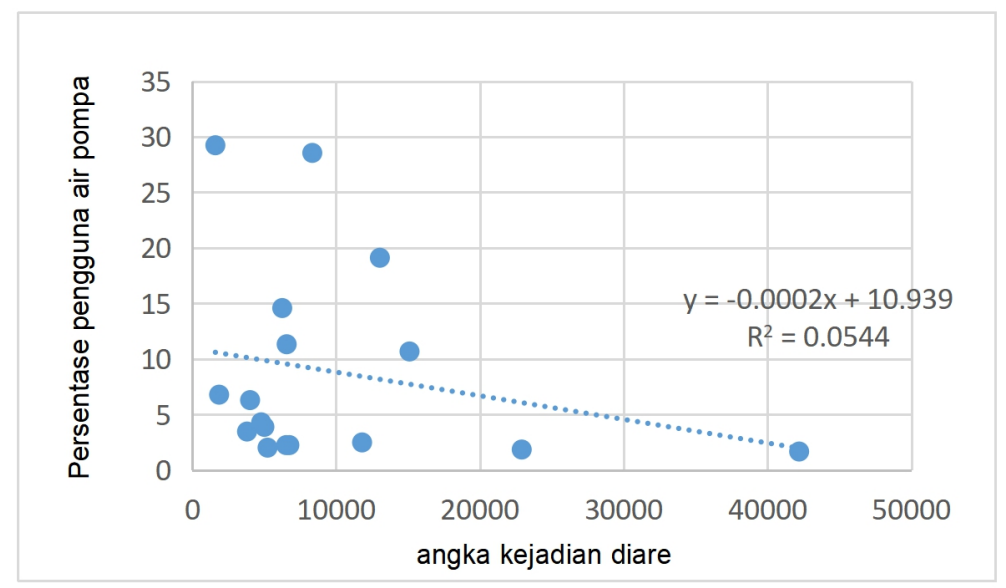

Gambar 2. Scatterplot kejadian diare dan air pompa 
Berdasarkan diagram pencar (Gambar 2), diperoleh angka $R$ square $\left(R^{2}\right)$ sebesar 0,054 atau $5,4 \%$ yang artinya hubungan sumber air minum air pompa dengan kejadian diare di Provinsi Sumatera Selatan sangat tidak erat.
Hubungan bersifat negatif secara statistik, yang artinya makin sedikit yang menggunakan air pompa maka kemungkinan yang mengalami diare akan semakin banyak.

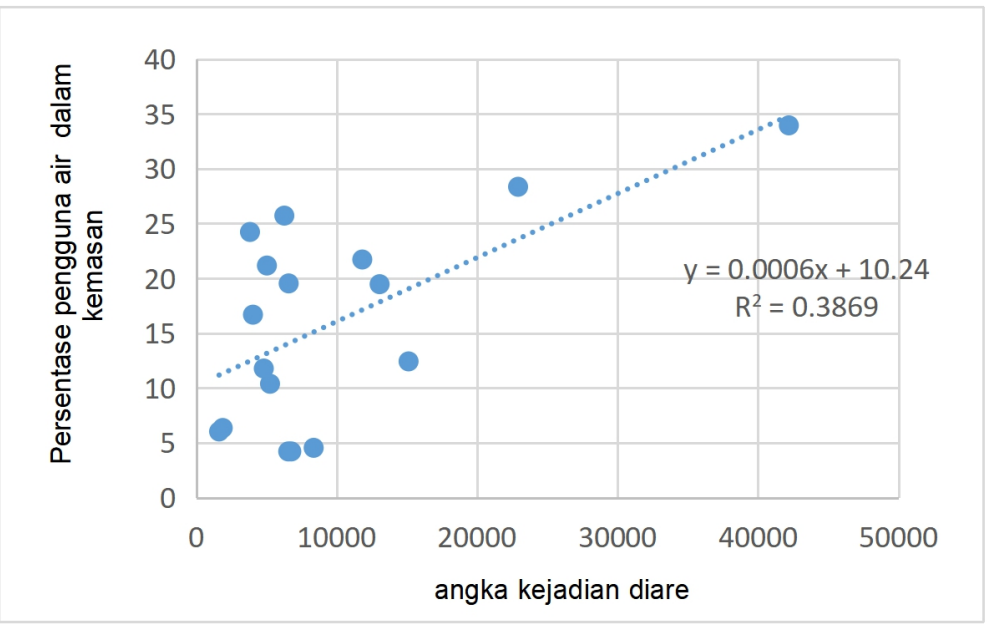

Gambar 3. Scatterplot kejadian diare dan air dalam kemasan

Gambar 3 menunjukkan diagram pencar hubungan antara angka kejadian diare dan persentase pengguna sumber air minum dari air dalam kemasan di Provinsi Sumatera Selatan dengan nilai $\mathrm{R}$ square sebesar 0.3869 atau $38,7 \%$ yang artinya bahwa hubungan kedua variabel tersebut tidak erat. Hubungan ini secara statistik cenderung bersifat kearah positif yang berarti bahwa jika pengguna sumber air minum dalam kemasan meningkat, maka angka kejadian diare kemungkinan akan meningkat juga, tetapi kemungkinan peningkatan ini juga dapat dipengaruhi oleh faktor yang lain.

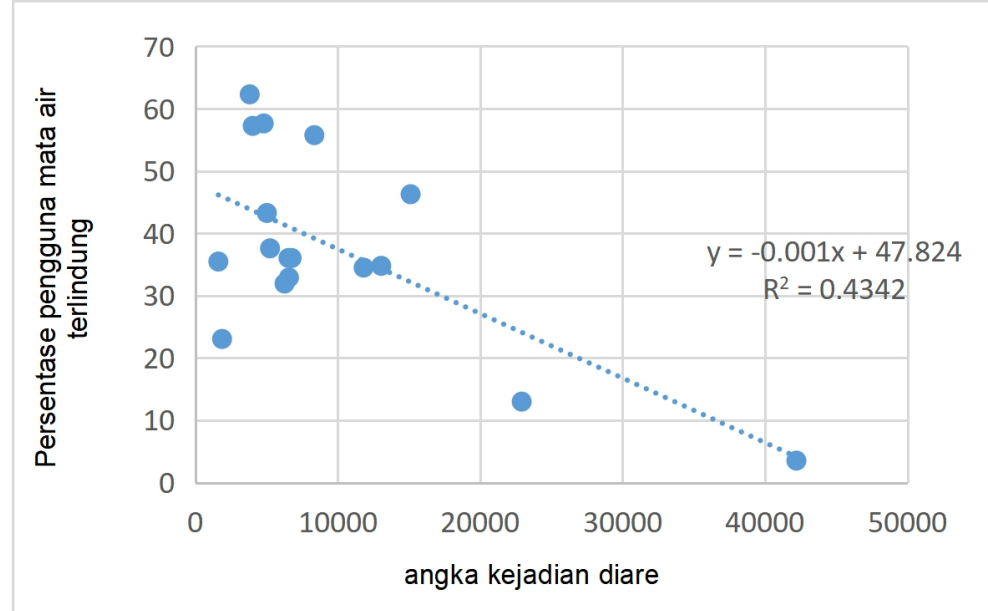

Gambar 4. Scatterplot kejadian diare dan sumur terlindung

Diagram pencar pada gambar 4 diatas, menunjukkan nilai $\mathrm{R}$ square sebesar 0,4342 atau $43,4 \%$ yang artinya hubungan sumber air minum dari sumur terlindung dengan kejadian diare di Provinsi Sumatera Selatan tidak erat. Secara statistik hubungan keduanya ada kecenderungan bersifat negatif berarti bahwa bila pengguna sumber air minum dari sumur terlindung makin banyak maka kemungkinan terjadinya kejadian diare akan menurun. 
Hubungan sumber air minum dari sumur tak terlindung dengan kejadian diare di Provinsi Sumatera Selatan digambarkan pada diagram pencar pada Gambar 5. Secara statistik tidak nampak adanya hubungan antara kedua variabel tersebut. Besarnya angka $\mathrm{R}$ square yang diperoleh adalah sebesar 0,0222 atau $2,2 \%$ yang artinya bahwa hubungan kedua variabel tersebut sangat tidak erat.

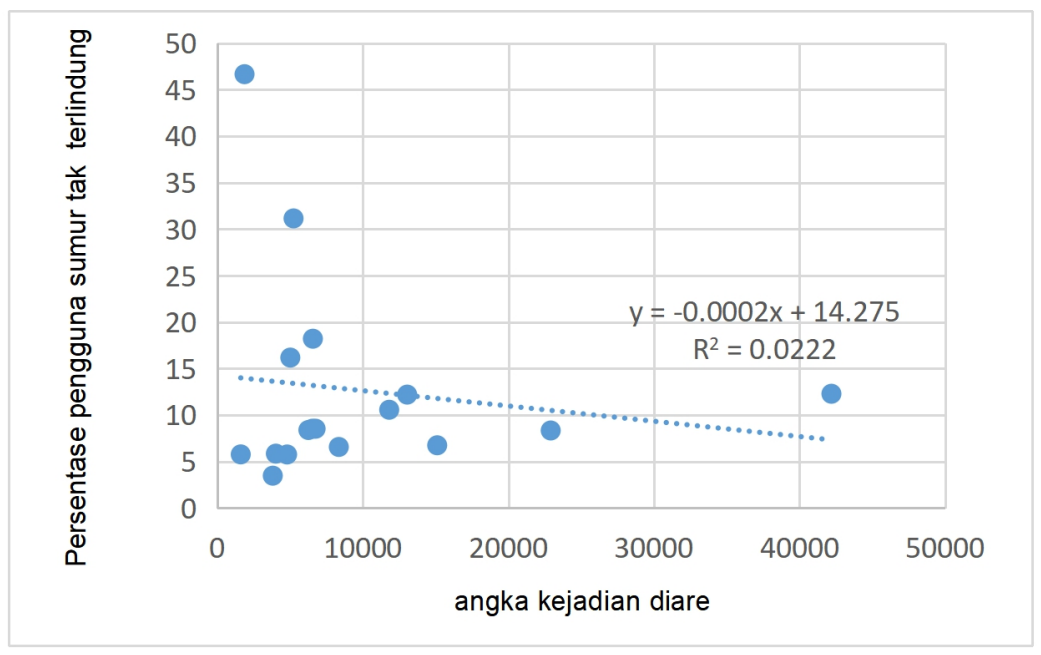

Gambar 5. Scatterplot kejadian diare dan sumur tak terlindung

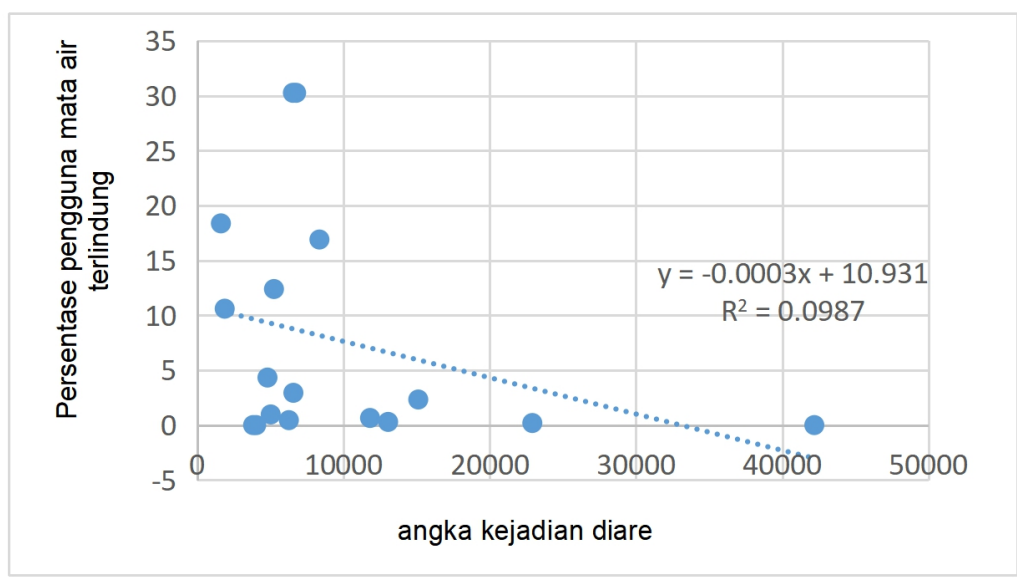

Gambar 6. Scatterplot kejadian diare dan mata air terlindung

Hubungan sumber air minum dari mata air terlindung dengan kejadian diare di Provinsi Sumatera Selatan berdasarkan diagram pencar diatas (Gambar 6), secara statistik cenderung bersifat negatif yang artinya semakin tinggi pengguna sumber air minum dari mata air terlindung maka angka kejadian diare akan semakin berkurang. Nilai $\mathrm{R}$ square yang diperoleh hanya sebesar 0,0987 atau 9,8\% yang berarti bahwa hubungan kedua variabel tersebut sangat tidak erat. 


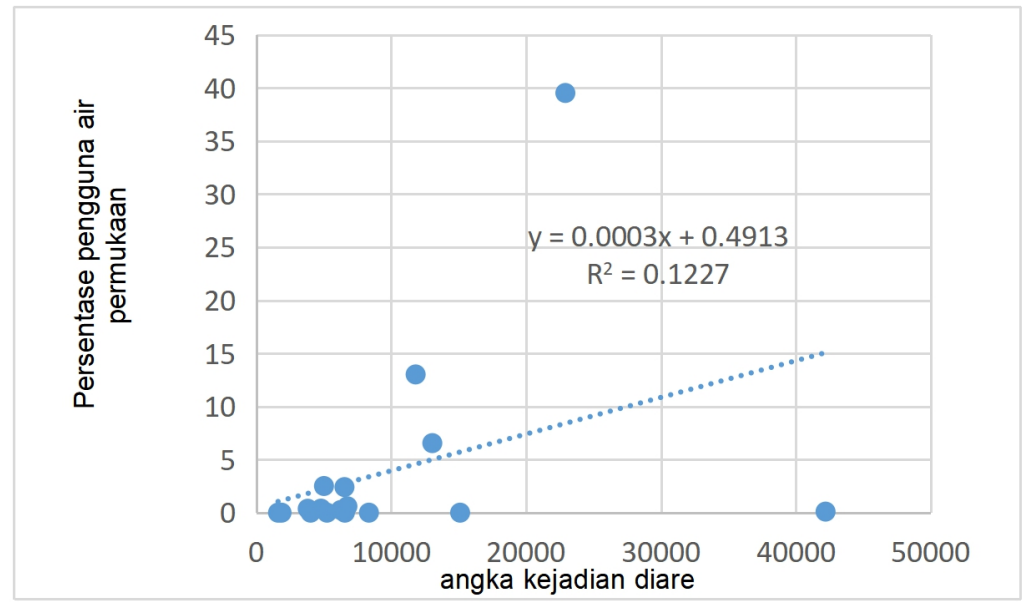

Gambar 7. Scatterplot kejadian diare dan air permukaan

Berdasarkan diagram pencar diatas (Gambar 7), diketahui bahwa secara statistik tidak nampak adanya hubungan antara kejadian diare dengan sumber air minum dari air permukaan. Besarnya angka
$\mathrm{R}$ square yang diperoleh adalah sebesar 0,0222 atau $2,2 \%$ yang artinya bahwa hubungan kedua variabel tersebut sangat tidak erat.

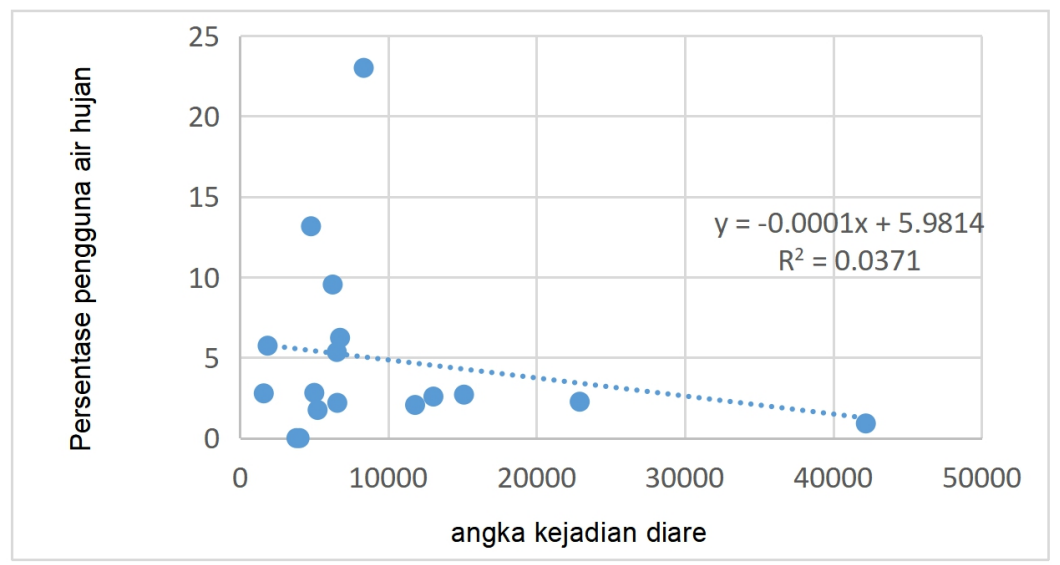

Gambar 8. Scatterplot kejadian diare dan air hujan

Berdasarkan diagram pencar diatas (Gambar 8), diperoleh angka $\mathrm{R}$ square sebesar 0,1227 atau $12,3 \%$ yang berarti bahwa hubungan antara angka kejadian diare dengan pengguna sumber air minum air hujan sangat tidak erat. Secara statistik, hubungan ini cenderung bersifat positif artinya semakin banyak pengguna sumber air minum air hujan, maka kemungkinan angka kejadian diare cenderung meningkat juga.

\section{BAHASAN}

Ketersediaan air bersih menjadi faktor yang mempengaruhi angka kejadian diare. Banyak penelitian yang telah membuktikan bahwa ada hubungan antara ketersediaan air bersih dengan angka kejadian diare, diantaranya adalah Damayanti (2017), yang menyatakan bahwa keluarga dengan ketersediaan air bersih yang kurang memiliki risiko lima kali lebih besar terkena diare dibandingkan dengan keluarga yang memiliki ketersediaan air bersih yang baik. Padji dan Sudarmadji (2017) mengatakan bahwa semakin rendah ketersediaan air bersih, maka peningkatan kejadian diare semakin tinggi. ${ }^{21}$ Menurut Utami \& Handayani (2017) bahwa ketersediaan air bersih berperan dalam penurunan kejadian diare pada anak dan memberikan kontribusi pada penurunan angka kematian anak akibat diare..$^{22}$ 
Untuk mengatasi masalah ketersediaan air bersih ini, Pemerintah telah membuat sarana air bersih yang dikelola oleh pemerintah daerah maupun swasta, seperti PDAM, DAMIU, dan lain-lain. Winenti dkk (2016) mengatakan bahwa sarana air bersih adalah suatu fasilitas umum yang bertugas untuk menyediakan dan mendistribusikan air kepada masyarakat. Sarana air bersih harus memenuhi syarat kesehatan agar tidak mengalami pencemaran, sehingga diperoleh air dengan standar kesehatan yang baik. ${ }^{23}$

Hasil analisis yang dilakukan memperlihatkan adanya hubungan dengan arah positif antara angka kejadian diare dengan sumber air minum air ledeng, yang berarti bahwa semakin tinggi penduduk yang menggunakan air ledeng sebagai sumber air minum maka akan meningkatkan kejadian diare di Provinsi Sumatera Selatan. Seperti yang kita ketahui bahwa air ledeng termasuk sebagai sumber air minum yang layak, tetapi hal ini tidak menjadi jaminan bahwa pengguna air ledeng akan terbebas dari risiko diare. Hal ini sesuai dengan analisis untuk Kota Palembang yaitu sebagian besar penduduknya telah menggunakan sumber air minum air ledeng, tetapi didapatkan angka kejadian diare yang lebih tinggi jika dibandingkan dengan kabupaten/kota lain yang kebanyakan penduduknya menggunakan sumber air minum yang lain. Komarulzaman et.al (2017) menyatakan bahwa penggunaan air ledeng/perpipaan memang diharapkan dapat meningkatkan derajat kesehatan masyarakat. Tetapi karena adanya sambungan perpipaan pada air ledeng, sehingga hal ini tidak dapat menjamin air ledeng tidak terkontaminasi. Selain itu, pada daerah dengan aliran air yang tidak mengalir secara terus menerus menyebabkan rumah tangga harus menyimpan air dirumah, penyimpanan air ini rentan terkontaminasi patogen berbahaya. ${ }^{24}$ Hasil penelitian yang dilakukan oleh Putra (2015) di Bali juga mendapatkan hasil bahwa warga yang menggunakan air PDAM dan air hujan sebagai sumber air minum cenderung mengalami diare jika dibandingkan dengan warga yang menggunakan air kemasan sebagai sumber air minumnya. ${ }^{25}$
Berdasarkan hasil penelitian yang telah dilakukan sebelumnya, bahwa masih banyak ditemukan patogen pada instalasi air PDAM, diantaranya yaitu penelitian yang dilakukan oleh Khoeriyah dan Anies (2015) menemukan bahwa dari 8 sumber air baku DAMIU yang di uji laboratorium terdapat 2 sumber air baku yang mengandung bakteri Coliform walaupun kandungannya masih memenuhi baku mutu sumber air sehat. Sumber air baku diambil dari mata air terlindung dan Perusahaan Air Minum (PDAM). ${ }^{26}$ Wulandari dkk (2015) mengatakan bahwa kualitas air produksi DAM semakin menurun dengan permasalahan antara lain adanya peralatan DAM yang tidak dilengkapi dengan alat sterilisasi atau mempunyai daya bunuh yang rendah terhadap bakteri. Berdasarkan hasil penelitian yang mereka lakukan didapatkan bahwa higiene dan bakteriologis DAM disebabkan oleh kurangnya sanitasi pada DAM serta peralatan yang tidak memadai. ${ }^{27}$ Penelitian yang dilakukan oleh Suseno dan Widyastuti (2017) juga menemukan bahwa pada air PDAM Tirta Manggar juga ditemukan kandungan bakteri Coliform yang melebihi batas ambang sumber air baku yang diperbolehkan sebagai sumber air baku. ${ }^{28}$ Rusly dkk (2019) juga menemukan bahwa kualitas air pada instalasi pengolahan Air Vatutela belum memenuhi syarat kesehatan karena masih ditemukan bakteri coliform/Escheria coli. ${ }^{29}$ Kandungan bakteri Coliform pada sumber air baku untuk PDAM ini kemungkinan dapat disalurkan melalui sistem perpipaan dan jika tidak diolah dengan baik, maka dapat menyebabkan berbagai penyakit perut salah satunya adalah diare. ${ }^{28}$

Tingginya angka kejadian diare pada masyarakat yang menggunakan air ledeng sebagai sumber air minum kemungkinan disebabkan adanya kontaminasi kuman/bakteri penyebab diare pada sumber air minum, selain itu dapat juga disebabkan oleh kurangnya higiene dan sanitasi dari perilaku masyarakat itu sendiri. Hal ini dijelaskan oleh Devina (2017) melalui penelitian yang mengatakan bahwa faktor faktor yang dapat mempengaruhi kualitas air bersih dengan sampel air PDAM disebabkan oleh faktor mikrobiologi. Terjadinya pencemaran mikrobiologi ini kemungkinan disebabkan karena adanya 
kebocoran pipa, kondisi sumber air dan kondisi tempat penampungan air. ${ }^{30} \mathrm{Hal}$ ini juga pernah diungkapkan oleh Susanti dkk (2016) yang mengatakan bahwa adanya kontaminasi bakteri baik pada sumber maupun pada penyimpanan akan meningkatkan risiko terjadinya diare. Selain itu selain dilihat dari sumber air minum, cara pengolahan air minum juga mempengaruhi kualitas air minum masyarakat. ${ }^{31}$ Komarulzaman et.al (2017) menyebutkan bahwa peningkatan kualitas air dan sanitasi yang baik secara bersamaan akan memberikan perlindungan yang efektif terhadap kejadan diare. ${ }^{24}$

Pada beberapa daerah tertentu, seperti di Kabupaten Banyuasin masih mengalami masalah sulitnya akses masyarakat ke sumber air minum yang layak. Kurangnya akses masyarakat ke sumber air bersih yang layak, menyebabkan masyarakat mengambil alternatif lain untuk memenuhi kebutuhan air sehari-hari, salah satunya adalah memanfaatkan air hujan. Menurut Indriatmoko dan Rahardjo (2015), bahwa air hujan dapat digunakan sebagai sumber air bersih untuk memenuhi kebutuhan air minum, tetapi dalam pemanfaatannya air hujan harus diolah terlebih dahulu karena didalam air hujan masih terkandung patogen yang dapat membahayakan kesehatan. ${ }^{32} \mathrm{Hal}$ ini sejalan dengan penelitian yang dilakukan oleh Anuar dkk (2015), bahwa berdasarkan hasil laboratorium terhadap kandungan air hujan, didapatkan bahwa air hujan masih bisa dikonsumsi dan tidak berdampak bagi kesehatan, tetapi didalam air hujan masih ditemukan kandungan bakteri Coliform yang melebihi batas baku mutu kesehatan, sehingga diperlukan pengolahan yang baik sebelum dikonsumsi. ${ }^{33}$ Yanti dan Harudu (2019), juga mengemukakan pendapat yang sama, bahwa air hujan secara fisika dan kimia memiliki kualitas sebagai sumber air minum. ${ }^{34}$

Berdasarkan hasil analisis data yang dilakukan, maka perlu dilakukan edukasi ke masyarakat mengenai higiene dan sanitasi lingkungan, pengolahan dan penyimpanan air sebelum digunakan untuk menurunkan angka kejadian diare. Hal ini dikarenakan walaupun sumber air minum yang digunakan sudah berasal dari sumber air minum yang layak, tetapi angka kejadian diare tetap tinggi. Hal ini telah dijelaskan oleh Iqbal et.al (2015) bahwa perlu dilakukan promosi kesehatan terkait perilaku kebersihan lingkungan, dan sanitasi, pengolahan dan penyimpanan air serta penanganan sumber air yang tepat untuk meningkatkan kualitas air dan dapat menurunkan angka kejadian diare. ${ }^{35}$ Penelitian yang dilakukan oleh Arimbawa dkk (2014) mendapatkan hasil bahwa perilaku memasak air minum merupakan faktor yang paling berpengaruh secara signifikan terhadap kejadian diare. ${ }^{36} \mathrm{Hal}$ ini sesuai dengan penelitian yang dilakukan oleh Mahmudah (2017) bahwa selain sumber air yang harus sehat, pengolahan air minum sebelum dikonsumsi juga mempengaruhi terjadinya kejadian diare pada anak balita. ${ }^{37}$ Winenti dkk (2017) menjelaskan bahwa selain sumber air minum, perilaku masyarakat dalam mengolah air minum lebih berpengaruh terhadap kejadian diare, diantaranya yaitu perilaku menyimpan air dalam wadah tertutup dan tidak tertutup, perilaku mencuci tangan dengan sabun sesudah buang air besar, dan perilaku merebus air sampai mendidih sebelum diminum. ${ }^{23}$

\section{KESIMPULAN}

Berdasarkan hasil analisis yang dilakukan terhadap delapan sumber air minum yang digunakan oleh masyarakat di Provinsi Sumatera Selatan diketahui bahwa sumber air minum air ledeng mempunyai hubungan yang kuat dengan kejadian diare. Secara statistik hubungan kedua variabel tersebut bersifat positif yang berarti bahwa semakin banyak masyarakat yang menggunakan air ledeng sebagai sumber air minum sehari-hari, maka angka kejadian diare akan semakin tinggi.

\section{SARAN}

Berdasarkan hasil analisis diketahui bahwa walaupun menggunakan sumber air minum yang dianggap cukup baik, seperti sumber air minum air ledeng, risiko terkena penyakit diare tetap ada. Maka untuk mengurangi kasus kejadian diare di masyarakat perlu dilakukan edukasi kesehatan ke masyarakat terkait dengan higiene dan sanitasi lingkungan, cara pengolahan dan penyimpanan air sebelum 
digunakan untuk keperluan sehari-hari. Dan untuk pihak pengelola air ledeng tersebut wajib rutin melakukan pengecekan kualitas air dan memastikan air yang dialirkan dalam kategori aman dan sehat.

\section{KONTRIBUSI PENULIS}

Penulis pertama sebagai kontributor utama dan penulis kedua dan penulis ketiga sebagai kontributor anggota

\section{UCAPAN TERIMA KASIH}

Terima kasih yang sebesar-besarnya penulis sampaikan kepada Kepala Badan Penelitian dan Pengembangan Inovasi Daerah Provinsi Sumatera Selatan dan staff, Bapak Endan Suwandana selaku tutor pada workshop penulisan karya tulis ilmiah bersama peneliti, dosen, dan pejabat fungsional tertentu lainnya di Balitbangda Provinsi Sumatera Selatan yang telah membimbing penulis selama workshop. Semoga artikel ini dapat bermanfaat bagi masyarakat pada umumnya dan kemajuan ilmu pengetahuan pada khususnya

\section{DAFTAR PUSTAKA}

1. Pesnita A, Hasanuddin, Suarnianti. Hubungan antara Perilaku Hidup Bersih dan Sehat dengan Kejadian Diare dalam Rumah Tangga di Wilayah Kerja Puskesmas Batu Batu Kec. Marioriawa Kab. Soppeng. J IIm Kesehat Diagnosis. 2014;4(6):721727.

2. Pertiwi TS. Penggunaan Sistem Informasi Geografis Untuk Pemetaan Sebaran Kejadian Diare Pada Balita Ditinjau Dari Faktor Lingkungan Rumah Keluarga di Kota Kendari. Indones Heal Inf Manag J. 2019;7(1):8-15.

3. Marlina G.O. Soentpiet, Jeanette I.Ch.Manoppo, Wilar R. Hubungan Faktor Sosiodemografi dan Lingkungan dengan Diare pada Anak Balita di Daerah Aliran Sungai Tondano. J e-Clinic. 2015;3(3):820825.

4. Utami N, Luthfiana N. Faktor-Faktor yang Memengaruhi Kejadian Diare pada Anak. Majority. 2016;5(4):101-
106.

5. Smith WBA. Acute Diarrhoea in Adults. Aust Fam Physician. 2014;89(3):180-189. doi:10.1136/bmj.b1877

6. Humrah, lis $S$, Amelia W, Mukarramah. Gambaran Pengetahuan Ibu Balita Dalam Penanganan Awal Balita Diare Di Desa Bone Kec. Bajeng Kab. Gowa Tahun 2017. J Bidan "Midwife Journal." 2018;5(01):1-7.

7. World Health Organization. Diarrhoeal disease. who.int. https://www.who.int/news-room/factsheets/detail/diarrhoeal-disease. Published 2017.

8. Kementerian Kesehatan RI. Laporan Hasil Riset Kesehatan Dasar (Riskesdas) Indonesia tahun 2018. Ris Kesehat Dasar 2018. 2018:182183.

9. Candra $Y$, Hadi MC, Yulianty AE. Hubungan Antara Keadaan Sanitasi Sarana Air Bersih Dengan Kejadian Diare Pada Balita Didesa Denbantas Tabanan Tahun 2013. J Kesehat Lingkung. $\quad$ 2014;4(1):112-117. http://poltekkesdenpasar.ac.id/files/JURNAL KESEHATAN LINGKUNGAN/Yennie Candra1, M Choirul Hadi2, Anysiah Elly Yulianty3.pdf.

10. Fajar ARDAPNA. Investigasi Kasus Diare pada Balita di Kota Palembang Tahun 2015-2016 dengan Pendekatan Sistem informasi Geografis. JKMA (Jurnal Kesehat Masy Andalas) (Andalas J Public Heal. 2018;12(2):90-96.

11. Katiandagho D, Darwel D. Hubungan Penyediaan Air Bersih dan Jamban Keluarga Dengan Kejadian Diare Pada Balita Di Desa Mala Kecamatan Manganitu Tahun 2015. J Sehat Mandiri. 2019;14(2):64-78. doi:10.33761/jsm.v14i2.118

12. Azmy P. Association Between Environmental Conditions Personal Hygiene Sanitation of Mother and Diarrhea Insident in Children at 
Working of Area Health Watukumpul District Pemalang. J Kesehat Masy. 2015;3(1):540-548. doi:10.1017/CBO9781107415324.00 4

13. Marinawati, Marta. Hubungan Antara Sanitasi Lingkungan Dengan Kejadian Diare Pada Balita Di Wilayah Kerja Puskesmas Limbur Lubuk Mengkuang Kabupaten Bungo Tahun 2013. Sci J. 2014;3(1):6-14.

14. Biantoro HFRSWHS. Faktor-Faktor yang Berhubungan dengan Kejadian Diare di Desa Solor Kecamatan Cermee Bondowoso. nurseline $\mathrm{J}$. 2016;1(1):24-35.

15. Wandansari AP. Kualitas Sumber Air Minum Dan Pemanfaatan Jamban Keluarga Dengan Kejadian Diare. KESMAS - J Kesehat Masy. 2013;9(1):24-29. doi:10.15294/kemas.v9i1.2826

16. Feby Victiani Ayuningrum MS. Analisis Faktor Sanitasi dan Sumber Air Minum yang Mempengaruhi Insiden Diare Pada Balita di Jawa Timur dengan Regresi Logistik Biner. $J$ Sains dan Seni. 2015;4N(2):223228.

doi:0.12962/j23373520.v4i2.10799

17. Nurpauji SV. Hubungan Jenis Sumber Air, Kualitas Bakteriologis Air, Personal Hygiene Dengan Kejadian Diare Pada Balita Di Wilayah Kerja Puskesmas Lamper Tengah Semarang. J Kesehat Masy. 2016;3(1):569-578.

18. Zarkasih MR, Rohmat D, Nur DM. Evaluasi Ketersediaan dan Tingkat Pemenuhan Kebutuhan Air di SUB DAS Cikeruh. J Pendidik Geogr. 2018;18(1):72-80.

doi:10.17509/gea.v18i1.9867

19. Suryani AS. Persepsi Masyarakat Dalam Pemanfaatan Air Bersih (Studi Kasus Masyarakat Pinggir Sungai di Palembang). Aspirasi. 2016;1(1):3348.

20. Statistik BP. Statistik Kesejahteraan Rakyat. (Tangga SSR, ed.). Badan Pusat Statistik; 2018.
21. Padji HM, Sudarmadji. Curah Hujan, Kelembaban, Kecepatan Angin, Ketersediaan Air Bersih dan Kasus Diare di Daerah Kering Kupang. BKM $J$ Community Med Public Heal. 2017;33(10):475-482.

22. Utami S, Handayani SK. Ketersediaan Air Bersih untuk Kesehatan: Kasus dalam Pencegahan Diare pada Anak. In: Optimalisasi Peran Sains Dan Teknologi Untuk Mewujudkan Smart City. 2017:211-235. http://repository.ut.ac.id/7078/1/UTF MIPA2017-09-utami.pdf.

23. Winenti, Widiyanto $T$, Widyanto $A$. Hubungan Pencemaran Sumber Air dan Perilaku Ibu dengan Kejadian Diare pada Anak Balita di Desa Sirkandi Kecamatan Purwareja Klampok Kabupaten Banjarnegara Tahun 2016. Poltekkes E-Journal. 2016:350-359.

http://ejournal.poltekkessmg.ac.id/ojs/index.php/keslingmas/a rticle/viewFile/3114/737.

24. Komarulzaman A, Smits J, de Jong $E$ Clean water, sanitation and diarrhoea in Indonesia: Effects of household and community factors. Glob Public Health. 2017;12(9):1141-1155. doi:10.1080/17441692.2015.1127985

25. Putra MB. Gambaran Pemilihan Sumber Air Minum pada Penderita Diare di Desa Kintamani Kabupaten Bangli Bali Tahun 2015. Intisari Sains Medis. 2016;7(1):53-56.

26. Khoeriyah A. Aspek Kualitas Bakteriologis Depot Air Minum Isi Ulang ( DAMIU ) di Kabupaten Bandung Barat. MKB. 2015;47(5):137-143.

27. Suci Wulandari, Arum Siwiendrayanti, Anik Setyo Wahyuningsih. Higiene Dan Sanitasi Serta Kualitas Bakteriologis Damiu Di Sekitar Universitas Negeri Semarang. Unnes $J$ Public Heal. 2015;4(3):8-15. doi:10.15294/ujph.v4i3.6338

28. Nitasha Vaniandayani Suseno, M. Widyastuti. Analisis Kualitas Air PDAM Tirta Manggar Kota 
Balikpapan. J Bumi Indones. 2017;6(1):1-8.

29. Sfandy Rusly, Budiman, Nur Rismawati. Study Kualitas Air pada Instalasi Pengolahan Air Vatutela PDAM Kota Palu. J Kolaboratif Sains. 2019;1(1):167-174.

doi:http://doi.org/10.31934/jom

30. Swastika D. Analisis Kualitas dan Kelayakan Air PDAM pada Beberapa Usaha Katering di Kota Semarang. 2017.

http://repository.unika.ac.id/id/eprint/1 6294.

31. Susanti WE, Sunarsih E. Determinan Kejadian Diare pada Anak Balita di Indonesia (Analisis Lanjut Data SDKI 2012). J Ilmu Kesehat Masy. 2016;7(1):64-72.

32. Indriatmoko RH, Rahardjo N. Kajian Pendahuluan Sistem Pemanfaatan Air Hujan. J Air Indones. 2018;8(1):105-114. doi:10.29122/jai.v8i1.2387

33. Anuar K, Ahmad A, Sukendi. Analisis Kualitas Air Hujan sebagai Sumber Air Minum terhadap Kesehatan Masyarakat (Studi Kasus di Kecamatan Bangko Bagansiapisiapi).
Din Lingkung Indones. 2015;2(1):3239.

34. Dewi Yanti, La Harudu. Analisis Kualitas Fisika Air Hujan di Desa Darawa Berdasarkan Standar Kualitas Air Bersih di Kecamatan Kaledupaselatan Kabupaten Wakatobi. J Penelit Pendidik Geogr. 2019;4(1):70-81.

35. Iqbal $M$, Nastiti $A$, Muntalif BS. Improved But Not Always Safe: a Microbial Water Quality Analysis in Bandung Peri-Urban Households. 5th Environ Technol Manag Conf. 2015;(November):1-8.

36. Bin Ahmad Z, Arimbawa IW, Trisna Dew KA. Hubungan Faktor Perilaku Dan Faktor Lingkungan Terhadap Kejadian Diare Pada Balita Di Desa Sukawati, Kabupaten Gianyar Bali Tahun 2014. Intisari Sains Medis. 2016;6(1):8. doi:10.15562/ism.v6i1.14

37. Mahmudah. Studi Kasus Kejadian Diare Pada Anak Balita Di Wilayah Kerja Puskesmas Bayanan Tahun 2015. In: Prosiding Seminar Nasional IKAKESMADA "Peran Tenaga Kesehatan Dalam Pelaksanaan SDGs."; 2017:61-68. 